\title{
Remuneration Reforms and Welfare of Employees in Public Schools: Experience From Nigeria
}

\author{
Akabom Ita Asuquo $^{1}$, Arzizeh Tiesieh Tapang ${ }^{2}$, Glory Tony Effiong ${ }^{1}$, Mkpa Ubuo Linus ${ }^{1}$, Ashishie Peter Uklala ${ }^{1} \&$ \\ Sylvester Bassey Duke ${ }^{1}$ \\ ${ }^{1}$ Accounting Department, Faculty of Management Sciences, University of Calabar, Calabar, River State, Nigeria \\ ${ }^{2}$ Department of Accounting, College of Management Sciences, Michael Okpara University of Agriculture Umudike, \\ Abia State, Nigeria \\ Correspondence: Akabom Ita Asuquo, Accounting Department, Faculty of Management Sciences, University of \\ Calabar, Calabar, River State, Nigeria. Tel: 234-806-646-8333.
}

Received: October 4, 2020

Accepted: December 21, 2020

Online Published: January 17, 2021

doi:10.5430/rwe.v12n2p113

URL: https://doi.org/10.5430/rwe.v12n2p113

\begin{abstract}
The survey was undertaken to ascertain the impact of remuneration reforms on the workers' welfare in public schools taking evidence from Nigeria. Facts were gotten by the use of a planned inquiry form and the data collected were then evaluated by means of the multiple regression techniques. Outcomes showed that there is a substantial impact of indicators of remuneration reforms on the welfare pointer (consumption) of employees in public schools. The negligible inclination to consume of employees with minimum remuneration, as well as employees with excessive remuneration, had revealed that these two categories put apart a huge percentage of their earnings for consumption to improve their welfare status and satisfaction level. Actions suggested to augment employees' wellbeing and propensity comprise of periodic remuneration rising assessment, regulation of price increases ratio in addition to setting up of nutrition subsidizations for employees in public schools by the government.
\end{abstract}

Keywords: consumption, employees, Nigeria, public, reforms, remuneration, schools, welfare

\section{Introduction}

Salary, wages, or remuneration performs a vital and critical part of the well-being of persons/employees. It is well established that the civic division remains the premier provider of employment. Whereas, remuneration reforms explain changes that may occur from time to time in the remuneration method. These changes may lead to either upward or downward reviews in the parameters that can be used to ascertain total remuneration at any point in time. These parameters as assumed in this investigation include the following, though not limited to them: Minimum remuneration [Min. R], Maximum remuneration [Max. R], Rent allowance [RA], Dependent allowance [DA], Transport allowance [TA], and Inflation [INFL] as the control variable. Employment in public schools or service has in actuality been obviously below-rewarded or poorly rewarded, with public schools' workers receiving a prejudiced paltry remuneration, which might scarcely pay for three-square banquets or meals a day. Remunerations and salaries had been stagnant in our country for several decades without an instrument to regulate remunerations to twinset the vibrant situation of frugality. Remunerations of workers in public schools continue to be static notwithstanding the prevalence of price increases in goods and chattels plus services. As a result, several families circle and homes exist beneath the paucity reflective.

For continued existence reason; public schools' workers have recourse to unconventional and unethical ways of complementing their earnings and remunerations by means of inducement in addition to exploitation, malingering, and unproductive. It should be that many regimes have evolved several reforms in order to improve the welfare of public schools' workers and these have proved abortive leading to complaints by these workers. Centered on the above realities, the investigation was conceded to evaluate minimum remuneration reforms and the welfare of employees in public schools, assessing the influence of price increases as the control variable on the acquiring influence of the remunerations and wages of workers in the public schools; and the category of these workers that has an utmost effect; in addition to the influences by the government in mitigating the challenges faced by the workers (Udoayang \& Asuquo, 2009, Budget of Realism [BoR],1999, Longe, 2007, Asuquo, 2012a). The practical and logical discoveries displayed in this study synchronously with other similar studies is that there is a positive and affirmative relationship 
between public schools employees' welfare and pointers of remuneration reforms in Cross River State. This is consistent with most of the notions explained in this exploration and also in agreement with the submissions made by Lipsey (1982), Ndebbio (1997), and Longe (2007). Furthermore, from the econometric point of view, we reported that $\mathrm{R}$-square $\left(\mathrm{R}^{2}\right)$ of 0.68 means that the explanatory and instructive variables, the pointer of public schools employees' welfare, explained about 70 percent of the variations in this dependent variable (Consumption of public schools' employees) in real and material life situations. Nevertheless, we can be optimistic that there is would be no bias and conflict in the data used for substantiation and authentication in this exploration.

\section{Literature Review}

\subsection{Assumptions of Basic Remuneration and Consumption}

Several existences afore the periodicals exhibition of the universal philosophy, several economists and analysts contended that consumption, as well as remunerations, is practically interrelated. Consumption in this exploration is regarded as a measure or pointer to welfare a person/remunerations earner. Friedman (1953) and Ndebbio (1997) nevertheless, recognized constructing correlation to macroeconomic principle, by allowing the level of consumption, which is the only major constituent of collective request, and could be precisely projected; the borderline the inclination to consume would be smaller than one; the normal inclination to consume reduces as disposable earnings rises. Unconditional earnings/remunerations proposition is so-called since the philosophy obviously accepts that consumption is determined whichever by domestic or country's unconditional wages.

\subsection{Lifespan Assumption and Consumption Pattern of Public Schools' Employees}

The proclamation of this assumption starts with the realistic detail that the normal personality's earnings and remunerations are lesser at the commencement as well as at the culmination of lifespan, except in the course of the intermediate ages. The lifespan assumption reasons that intensification of the normal personality's convenience yields a feeding rivulet that is continuous or increases marginally and ultimately. It is presumed that the consumers make the most of effectiveness with respect to the restriction that the current worth of the feeding and consumption stream might not outstrip the current worth of the earnings and wages stream. Assumed the purpose of a continuous is somewhat increasing intake rivulet plus earnings rivulet that increases before decreases, the persons would customarily be a disposable debtor while undeveloped, a mesh borrower in the intermediate ages to pay back previous obligations plus getting ready for superannuation as well as mesh dis-borrower in superannuation and/ or retirement. Lifespan assumption could explicate the non-relative concerning consumption besides earnings and remunerations that are perceived in fractious-segmental consumption inquiries by employees in the public schools (Budget of Realism [BoR], 1999, Longe, 2007).

Postulate that an unsystematic drawing of family units as of the inhabitants especially those in public employment, agreeing to their earnings and remunerations is taken. Family units with greater than normal earnings and remunerations might lean towards the inconsistent numeral of intermediate venerable earnings and remunerations recipients, exactly so since these inhabitants fragment receives greater than normal earnings and remunerations. Contrariwise, individual family units with fewer than normal earnings have a tendency to encompass an inconsistent digit of whichever fledgling or hoary earnings recipients since the fledgling as well as hoary lean towards receiving lower than normal wages. Agreeing to the lifespan assumption, the normal inclination to consume of intermediate hoary (extraordinary-wages) personalities would be lesser than the normal inclination to consume of whichever fledgling or hoary (small wages) personalities. Consequently, the normal inclination to consume family units will degenerate as wages increases (Friedman, 1953).

\subsection{The Link Between Perpetual Earnings Assumption and Consumption of Employees in Public Schools}

Perpetual earnings assumption takes responsibility that family units or households accord as ample significance to the intake of their beneficiaries as they see to their individual intake. Perpetual earnings are the rivulet of incomes as of a personality's treasure/riches. Treasure at this time comprises perceptible plus non-perceptible resources. An entity's transient earnings comprise of earnings gained in the recent era, which might diverge with fluctuating present circumstances. Perpetual earnings and transient earnings provide over-all earnings. Perpetual intake is the usual intake packages and specific requirements to consume. Similar to transient earnings and remunerations, we have also, transient consumption. Comparatively, they are the packages a person might consume during periods of both beneath and beyond the standard intake packages. Transient consumption is understood to be unconnected to transient earnings and remunerations, nevertheless, perpetual earnings and remunerations regulate perpetual in-taking. The postulation enhances the essentials of antiquity that is further than the total earnings/remunerations assumption obsession with present earnings and remunerations. The component of antiquity is imperative since personalities essentially 
acclimatize to historical involvements. Personality's entire intake might definitely be contingent on a particular treasure and riches idea. The proposition exertion to integrate the component of antiquity is, consequently, creditable. Prosperity and treasure might consist of artistic merchandises similar to scientific and high-tech awareness as well as expertise, benevolence, conservational rewards, wages, pension plus beneficial models in addition to morals motivation for public workers lead greater productivity and job satisfaction, which subsequently in better working conditions, improved standard of living and enhanced welfare packages for the workers (Friedman, 1953, Akpan, Asuquo,\& Tapang, 2014, Asuquo, Akpan, \& Tapang, 2012).

Essential, the end outcome is always achieved for the reason that each family unit that received perpetual earnings beneath the mockup's mediocre restrained earnings brace as a result of a progressive transient earnings constituent. We could deduce centered on the postulation, those earnings are generally circulated for comparable families. This is undoubtedly in mark with the meaning of lifespan premise. In a standard circulation, a digit of families beneath the normal perpetual earnings that might encounter decent prosperity as well as are provisionally hauled into the normal unhurried earnings brace is accurately harmonized earnings that might encounter hardship and are provisionally heaved despondent into the normal dignified earnings brace. Disagreement ambiances the postulation that temporary earnings are not connected to momentary consumption; it was not safe to maintain that all momentary earnings are set aside. Notwithstanding the deficiencies, the unqualified earnings supposition has continued to be an effective device for the elucidation of intake conduct predominantly on the verge. It symbolizes sagacity to accept as true that a superfluous piece of merchandise plus amenities expended in the present era could be determined by the extra piece of earnings gotten in the recent era. As argued by Effiong, Udoayang, and Asuquo (2011), there is a correlation between the current value of households' earning and the current cost of the amenities acquired by the households as a result of increases in current values as opposed to historical values.

\subsection{Concept of Income, Consumption, and Savings}

Earnings and wages are the aggregates of money expected by family units in compensation for the provision of elements of creation. It denotes the degree to which ones receive cash actively; consequently, individuals labor to receive earnings. And these frequently materialized and are rewarded by motives of expediency in the arrangement of currency. This category of earnings is currency earnings (Wusen, 2016, Stephen, 'unpublished 2019'). There are actual earnings, which processes family earnings in relationships of the grasp in excess of supplies that currency earnings convene. Placed laconically, earnings are the stream of remunerations that upshots commencing the inventory of riches and capital as recorded in the entity's financial documents based on the financial accounting standards and financial reporting practices (Asuquo, 2013). Glautier and Underdown (1990) observed that earnings are obtainable for feeding or a suggestion of the quantity currency. And this, individuals, could consume deficient draining their pockets. The above definition lays emphasis on the part of income to be consumed or disposable income. Consequently, not reusable earnings are the entirety of the earnings of all the personalities in the frugality next to all levies removal plus all relocation disbursements (Baumol \& Blinder, 1988). It could be understood as of the preceding deliberations that there are connections and affiliations amongst non-reusable earnings as well as feeding or intake by individual households.

This proclamation is deep-rooted by Lipsey (I982) when he alleged that different domestic feeding is linked to its not reusable earnings as well as cumulative feeding and consuming. Furthermore, end-user disbursement or intake is the entire mandate of entirely end-user merchandise in addition to amenities. End-users' outflows could be influenced by dint of expense degree; the anticipation of upcoming earnings; plus variations in relations of acclaim availability. Normally, end users' judgments are predisposed by the multiplicity of powers together with earnings, charge, charge ratio, riches plus prospects of earnings, and these are the greatest contributing factor of end-user expenditure. This is for the reasons that the percentage of end-user disbursements is unswervingly and meticulously connected to the expanse shoppers have to devote their nonrefundable earnings. Experience has shown that the further earnings an individual obtained within a certain period, the further he or she uses. Nevertheless, the greatest numbers of individuals do not expend every one naira they collect. They cope to set aside a certain part of their nonrefundable earnings even though it is insignificant. From the abovementioned, selected present intake, collectors accrue buying influence for feeding in future epochs.

\subsection{Aggregate Intake Function and Disposable Income of Employees in Public Schools}

Earnings and remunerations are obviously the most important determining factors of amassed and collective consumption. As averred by Asuquo (2011) creative accounting greatly impacts earnings and remunerations management in modern financial reporting of every organization that aimed at establishing effective and efficient remuneration, reward, and consumption pattern system. Nevertheless, further elements have an emotional impact on intake disbursement in run-through; they comprise the spreading of actual earnings and remunerations, the actual 
worth of domestic resources and properties stock, the proportion of investment income, as well as persons' inclinations and fondness. An investigation of families' outflow or disbursement pattern validates that cumulative intake or consumption is linked to actual earnings and remunerations ranks. These forms of investigations indicate that families in the upper ranges of earnings tend to set aside further proportionally than persons in less than earnings ranges. Yet again, the further similarly dispersed the entire family's earnings are, the larger the degree of prearranged intake related to it.

Additionally, prosperity consequence meaningfully elucidates the degree plus configuration of family's intake shopping basket; to families that delight in the identical side by side of earnings, as well as one which embraces bank securities, control securities, etc., in addition, while the other embraces not anything or a little moderately a reduced amount of wealth. This implies that the earlier domestic will in the wide-ranging blueprint has a greater than a degree of intake. Additionally, it is judicious to contemplate that families will strategize to set aside an extra amount out of their earnings if the level of interest were 20 percent rather than 5 percent. Selected persons who possibly will desire to consume on credits might be less enthusiastic to do so if the interest ratio is comparatively odd or high.

Consequently, the greater the level of interest, the further eager certain individuals drive to set aside and the fewer agreeable others will not set aside. The inclination is defined as the psychosomatic and emotional assertiveness of associates of buyers and users as acclimatized by conventional standards besides prices of the social order in which they exist in addition to have their rearing. A number of individuals are nurtured up to accept as true that to reserve income is a good point, which might be compensated in this all God's creatures or somewhere else. Others have confidence that a larger portion of earnings and remunerations must be consumed. Inclination impacts what individuals might agree to do with their wealth. Experiential investigations frequently adhere to fewer variables that present negligible measurability as well as combination problems, even though there are other influencing variables.

The upsurge in the inclination to consume should be abruptly differentiated from an upsurge in in-take. The earlier is an ascending transferences of the consumption plan; designating a variation in constraints that caused families to design a greater level of actual intake at every level of actual earnings. This is termed self-directed the upsurge in intake as it is self-sufficient with reverence to earnings. Comparatively, an upsurge in actually scheduled intake might arise merely for the reason that actual earnings increase and as an outcome, we interchange laterally an unaffected inclination to guzzle plan. This is termed prompted increase in intake owing to the upsurge in actual earnings and remunerations. Thus, the enhancement of the capability of the employees towards attainment of the maximum objective of the organization (Lipsey, 1982, Ndebbio, 1997, Budget of Realism [BoR], 1999, Longe, 2007, Uwah \& Asuquo, 2016).

\subsection{Concept of Inflation and Welfare Level of Employees in Public Schools}

Asuquo and Effiong (2010), Lawal (1985) averred that price rises in the current magnitude of cash short of a conforming upsurge in the magnitude of end-user merchandise as well as amenities which are swapped for cash are termed inflation. It denotes the epoch when excessively ample cash is pursuing too insufficient merchandise and this implies that an element of cash will purchase fewer numbers of merchandise. James and Richard (1982) explained inflation as an enduring increase in the level of charges such that it costs extra in buying the usual parcel of the merchandise plus service area preferred by consumers. Baumol and Blinder (1988) also opined that inflation is a continuous upsurge in the wide-ranging charge level; whereas Lipsey (1982) and Asuquo (2012a) submitted that inflation is an enlargement in the charge level. As of the above explanations, it could be inferred that inflation is an insistent wide-ranging increase in the charge of merchandises, amenities as well as elements of creation. Consequently, an increase in the charge of the goods comparative to the price level is not inflation.

\subsection{Effect of Inflation on the Value of Disposable Earnings of Employees in Public Schools}

\subsubsection{Inflation, the Value of Money, and the Prospect Cost of Keeping Cash at Hand During Inflationary Period}

Parkin (I989) averred that when price rises are contemporaneous; currency is depreciating in worth and purchasing strength. The worth and strength of the currency is the quantity and the volume of belongings, merchandises as well as amenities that could be purchased with a specified sum of currency. When a nation encounters price increases the worth of currency decreases or depreciates. Consequently, price rises diminishes and condenses the acquiring and buying influence and propensity of a country's economic and fiscal component. This upsets generally individuals with static and permanent earnings that do not increase in the matching percentage and quantity with price rises, for instance, the case public and domestic employees. For the reason that of the increasing prices of goods and chattels, amenities plus dynamics of invention, fabrications companies besides government might reduce employees in direction to 
bowdlerized cost in that way of instigating joblessness and idleness (Asuquo, Fadenipo, Ogbeche \& Ahonkai, 2017, Asuquo, 2012a, Asuquo \& Effiong, 2010, Effiong, Udoayang \& Asuquo, 2011).

Over and over again we emanate to the decision that price rises are upright for mortgagors and depraved for bankrollers or that mortgagors have the advantage while bankrollers are disadvantaged in the matching epoch. It is not price rises as such that yields the improvements or damages for mortgagors or creditors. It is an unexpected upsurge in the degree of price raises those paybacks mortgagors but discomforts financiers also an unimagined decline in the price rises discomforts pledgers (Lipsey, 1982, Axel, 1968, Asuquo, 2012a \& b, Asuquo \& Effiong, 2010). The expected price rises are price increases that are adjusted as well as projected on the normal range that founded the glitches of prospect and chance charge of stocking currency. Hereafter, the price rises ratio/level is the occasion charge of stocking currency whichever in the bank or a hand. This is for the reason that a price rise ratio of 10 percent might lessen the bulk of cash by the equal measurement (Federal Office of Statistics [FOS], 2019, Asuquo, 2012a, Asuquo \& Effiong, 2010).

\subsubsection{Effect of Price Changes Earnings of Workers and Administrators of Public Schools}

One more collective conviction is that price increases re-allocates earnings amongst workforces and administrators. Our price increases upsurge unpredictably, at that point remunerations will not have been fixed sufficiently. Earnings will be advanced than projected and remunerations will purchase fewer types of merchandise than anticipated (Udeme \& Akpan, 2016). Administrators and establishments have remarkable improvement at the detriment of employees. On the other hand, if the projected price rises ratio is advanced than whatever the real price raises ratio is obtainable, remunerations will have been fixed too extraordinary and revenues will be wiped away. Employees will be capable of purchase extra with their earnings than initially estimated. The consequence of price rises could likewise be observed as a re-allocated instrument. The notion is buttressed through Asuquo (2012b) and Bradley (I989) while they alleged that the micro penalties of price and interest rate rises are revealed in the reallocation of earnings and riches, increase in net assets; not wide-ranging decays in whichever procedures of the financial element in both public and business organizations. These reallocations take place since individuals purchase not the same mixture of merchandises and amenities possess dissimilar resources and vend numerous merchandises and amenities and investment in assets of $\mathrm{big} /$ multinational entities. Consequently, the effect of price increases on people hinge on in what way the charges of the merchandises as well as amenities every individual purchase or vends essentially adjust (Udeme \& Akpan, 2016, Timothy, 2018).

\subsection{Concept of Public Service and Workers in Public Schools}

A public service is a group, which relishes longevity of survival, and support in the conceiving, devising in addition to putting into practice government strategies and plans. Public service is further seen as an organization, configuration, or establishment, which handles the supervision, management and directing of government affairs and activities. It is an organization of skilled and proficient full-time bureaucrats in employment in the public and civic dealings of a government in a non-partisan organizational service. For those reasons, public service is a group of individuals who are unswervingly active in the direction of the interior dealings of a government or the public, whose starring function plus prominence are not partisan and dogmatic, parliamentary, armed or law enforcement (Longe, 2007, Salif, 1999, William \& Holen, 2003, Asuquo \& Akpan, 2014).

The public service and public schools have the ensuing features: Extreme public schools and public employees turn out to be experienced specialists in a subdivision of the civic organization, several of them with distinctive proficiency in such methodological areas as accounting, economics, and engineering besides technologies. They are considered as proficient advice-givers, teachers, tutors and gurus to those who articulate public strategies and programs; public service is systematized and structured along normal administrative secretarial stripe in which a manacle of thorough knowledge springs in hierarchical technique beginning with the bottommost to the uppermost. In direction to preserve the civil service scheme, the pecking order of officers is discernible by permanent positions with well-defined duties, specific powers, salaries and privileges; and permanence government may come and go but the public service remains to oil the wheel of government and public schools remain the basic training ground for the greater number of populace and tomorrow's world leaders. It is well observed that the Public Service Workers Union was designed in 1912 in Nigeria to discuss and handle the well-being, remunerations, and state of affairs of service for the affiliates of the public service (Ubeku, I975, Public Service Handbook [PSH], 1972, Chambers Dictionary [CD], 1982, Salif, 1999, William \& Holen, 2003). 


\subsection{Highlights of Motivation and Contributions of the Current Study}

As could be inferred from the foregoing literature review, this study was prompted by lack of good remuneration and reward method that can enhance the welfare and standard of living of workers in the public schools in Nigeria. The various pieces of literature presented above synthesized with the methodology adopted in this study for a verifiable result. Demonstrably, the remuneration method in public schools were not taking into consideration the inflation/interest rate instability, professionalism, etc. thus, resulting in a poor remuneration system with the negative effect of low welfare and poor standard of living of these workers. Therefore, there was a pressing need for this exploration in order to proffer a better and timely solution to the aforementioned problems. It is hereby submitted that the discoveries made in this study will contribute greatly to the methodology used in determining the remuneration of workers in public schools in Nigeria so as to enhance their welfare and standard of living.

\section{Materials and Methodology}

\subsection{Research Design}

Research design is the basic plan which guides the data collection, presentation and analysis phase of the research project (Asuquo, 2012c). The method used was desk survey, where the data collected from the questionnaire and various publications were summarized end tabulated. The data for the study were generated from both the primary and secondary sources. The primary sources were obtained from personal interview and questionnaires. The secondary data were through textbooks, journals and annual reports from the state secretariat.

\subsection{Population and Sample Size}

The population under study was the whole staff of Calabar, Cross River State's Public Schools, Nigeria. The applicable and appropriate respondents to a given research element and instrument were carefully chosen through an unambiguous and detailed statistical technique. A total of 400 respondents (200 low-ranking workers and 200 high-ranking senior workers) of grade level 01-06 and 07-16 correspondingly, were carefully chosen. The study was developed and technologically advanced to test whether there is any substantial correlation between the welfare pointers of Public School employees and lowest remuneration deriving evidence from Calabar, Cross River State, Nigeria (Component of Tenth National Plan [CONP], 1999-2001, Osuala, 1982, Nwana, 1981).

\subsection{Model Specification}

The specified model for the study was

$$
\begin{gathered}
\text { WOPSE }=f(\text { MRR }) . \\
\text { WOPSE }=b_{0}+b_{1} \text { Min.R }+b_{2} \text { Max.R }+b_{3} R A+b_{4} \text { DA }+b_{5} \text { TA }+b_{6} \text { INFL+U. }
\end{gathered}
$$

Definition of variables in the model:

WOPSE $=$ Welfare of Public Schools' Employees measured in terms of consumption

MRR = Minimum Remuneration Reforms measured in terms Min.R, Max.R, RA, DA, TA, and INFL as control variable;

MIN. $\mathrm{R}=$ Minimum Remuneration

MAX. R = Max. Remuneration

RA $=$ Rent Allowance

$\mathrm{DA}=$ Dependent Allowance

$\mathrm{TA}=$ Transportation Allowance

$\mathrm{U}=$ Unobserved error term.

$\mathrm{b}_{0}, \mathrm{~b}_{1}, \mathrm{~b}_{2}, \mathrm{~b}_{3}, \mathrm{~b}_{4}, \mathrm{~b}_{5}$, and $\mathrm{b}_{6}=$ Unknown coefficients to be estimated.

\subsection{Estimation and Validation}

The specified model above was estimated (tested) using the multiple regression coefficients of the variables and their respective $t$-values: The validation was based on examining the strength of the coefficient of determination $\left(R^{2}\right)$ by converting it into the test statistic (F), which measured the model explanatory ability. 


\section{Results and Discussions}

\subsection{Results}

Table 1. Regression result on impact of remuneration reforms (Independent variables) on welfare of Employees in public schools measured as consumption (Dependent variable)

\begin{tabular}{lllll}
\hline Parameters & Estimated coefficient & Standard error & T-worth & P-worth \\
\hline CONSTANT & 81.246 & 34.811 & 22.43 & 0.001 \\
\hline MIN. R & 6.721 & 0.055 & 9.66 & 0.003 \\
\hline MAX. R & 0.376 & 0.376 & 11.76 & 0.000 \\
\hline RA & 0.356 & 0.316 & 8.65 & 0.001 \\
\hline DA & 0.245 & 0.373 & 7.65 & 0.002 \\
\hline TA & 0.137 & 0.416 & 4.65 & 0.001 \\
\hline INFL & -0.452 & 0.356 & -5.65 & 0.001
\end{tabular}

$\mathrm{R} 2=0.687, \mathrm{~F}-\mathrm{RATIO}=60.63, \mathrm{D} . \mathrm{W}$ STATISTIC $=3.86$, ADJUSTED R2 $=0.55$

Source: Authors' analysis

\subsection{Discussions}

The exceeding table encapsulates the projected and review results, and the regression approximations of the effects of the designated pointer of welfare (here consumption) of public schools' employees on remuneration reforms grounded and established on statistics and pieces of evidence gathered from a cross-section of employees in Cross River State's public schools, Nigeria from 2006-2018 as reported by the Federal Office of Statistics [FOS], 2019. The exceeding equality demonstrates the regression results of the connection between dependent and explanatory variables over time integrating the remuneration reforms course of action and pointer welfare of employees in public schools. The reckoning appraises the impacts of remuneration reforms or negotiation on consumption patterns of the employees in public schools. The adjusted coefficient of multiple determinations from the result showed that 0.55 percent of the discrepancy in consumption as the pointer of the welfare of employees in public schools is jointly caused by disposable remuneration and disbursement of employees in public schools. The other 0.45 percent is captured by other factors which are incorporated in the model but represented by stochastic error terms, and these outcomes are similar to the findings of the empirical investigation by Udoayang and Asuquo (2009), Udeme and Akpan (2016).

The F-ratio of 60.63 being greater than table F-value at 5 percent level of significant implies that there is a high level of relationship between the pointer of welfare (consumption) of employees' public schools and remuneration reforms parameters. The assessed parameters of the two variables also suggest a linear relationship between the variables. The signs are unswerving with our guesses. The positive relationship between the welfare of employees in public schools and pointers of remunerations reforms; Minimum remuneration [Min. R], Maximum remuneration [Max. R], Rent allowance [RA], Dependent allowance [DA], Transport allowance [TA], is shown by the positive values of their regression coefficients except for the control variable which was assumed as inflation [INFL] and had indicated a negative coefficient in the model. However, they all showed significant interaction based on their respective t-values (see Table 1 above).

The pragmatic discoveries displayed that there is a positive relationship between public schools employees' welfare and pointers of remuneration reforms. This is consistent with most of the notions explained in this exploration and also in agreement with the submissions made by Lipsey (1982), Ndebbio (1997), and Longe (2007). Furthermore, from the econometric point of view, we report that R-square $\left(R^{2}\right)$ of 0.68 means that the explanatory variables, the pointer of public schools employees' welfare, explained about 70 percent of the variations in this dependent variable (Consumption of public schools' employees) in a real-life situations. Nevertheless, the values of Durbin Watson statistic of about 3.86 falls into the conclusive region, therefore we can finalized that there is no autocorrelation among the variables. 


\section{Conclusion}

The non-empirical outcomes exhibited that the numerous glitches and difficulties confronted by the public schools' workers especially during the period of inflation, without appropriate upward review of remunerations of public workers. These glitches and difficulties include insufficient remuneration to meet the continuing necessities of the family units; low welfare condition; and government indifferent attitudes in tackling remuneration reforms and matters. Therefore, having scrutinized the results, we are convinced that inflation has effects on the disposal remuneration of public school workers and these effects in no small way affect the standard of living and/ or welfare (which was assumed as consumption) of public school workers. That is to say if the remuneration increases, welfare and/ or the standard of living of employees in public schools will increase. This is so because prior economic conjecturing pointed out that a growing or buildup of disposable remunerations will boost the well-being of public school workers as deduced from this exploration, and supported by the findings made by Asuquo (2012a), Asuquo \& Effiong (2010) in their respective empirical investigations.

From the foregoing, the public service and public schools have the ensuing features: Extreme public schools and public employees turn out to be experienced specialists in a subdivision of the civic organization, several of them with distinctive proficiency in such methodological areas as accounting, economics, and engineering besides technologies. They are considered as talented advice-givers, teachers, trainers and gurus to those who articulate public strategies and programs; public service is systematized and structured along typical administrative secretarial line in which a chain of thorough knowledge springs in hierarchical technique beginning with the bottommost to the topmost (Asuquo \& Akpan, 2012, Asuquo \& Akpan, 2014)

Based on the outcomes of this exploration we suggested that the government should stimulate the production of more goods and services by developing infrastructures and paying more attention to agriculture and manufacturing sectors. It is envisaged that increase production of both agricultural and factory-made goods and services will cause prices to be steady. The government should advocate remuneration upsurge by steadying the prices of goods and services because a realistic salary increase of the civil servants will greatly improve their welfare. The government should design and implement welfare programs such as transport, canteen, housing, and health to enhancement the self-confidence and spirits of public schools workers hence increased productivity and efficient rendering of services by these workers. The data used for analysis in this study were only limited in time and scope to workers in public schools in Cross River State, Nigeria. Therefore, it was suggested that more elaborate future exploration be carried out in public and private schools in other states in Nigeria.

\section{Acknowledgements}

The authors sincerely acknowledge and thank the following group of persons though not exhaustive, for their direct and indirect contributions towards the successful completion of this investigation and report: Management and staff of Cross River State School Board, Federal Office of Statistics, and teachers in public school Calabar, Nigeria.

\section{Conflict of Interest}

The authors declare that there is no conflict of interest in the submissions made in this report

\section{References}

Akpan, A. U., Asuquo, A. I., \& Tiesieh, A. T. (2014). Wages and pension reforms and management in Nigeria. Journal of Management and Business Research, 2(1), 21-28.

Asuquo, A. I. (2011). Impact of creative accounting and earnings management on modern financial reporting. The Nigerian Academic Forum, 20(1), 1-6.

Asuquo, A. I. (2012a, May-June). Inflation accounting and control through monetary policy measures in Nigeria: Multi-regression analysis (1973-2010). IOSR Journal of Business and Management, I(2), 53-62. https://doi.org/10.9790/487X-0125362

Asuquo, A. I. (2012b). Impact analysis of interest rate on net assets of multinational business in Nigeria. Research Journal of Finance and Accounting, 3(7), 64-70.

Asuquo, A. I. (2012c). Empirical analysis of the impact of information technology on forensic accounting practice in Cross River State- Nigeria. International Journal of Scientific \& Technology Research, 1(7), 25-33.

Asuquo, A. I. (2013). Analysis of financial accounting standards and their effects on financial reporting and practices of modern business organizations in Nigeria. European Journal of Business and Management, 5(4), 60-68.

Asuquo, A. I., \& Akpan, A. U. (2012). Professional ethics as instruments for Effective and efficient financial 
management in the Nigerian public sectors: A scientific approach. International Journal of Advance Innovations Thoughts and Ideas, 1(6), 5-10.

Asuquo, A. I., \& Akpan, A. U. (2014). Professional proficiency for effective Accounting education and practice for coping with the changing world: Nigeria's perception. International Journal of Management Sciences, Research Academy of Social Sciences, 4(6), 241-252.

Asuquo, A. I., \& Effiong, S. A. (2010). Reporting the financial effects of price-level changes in globalized economy, Nigeria. International Journal of Management Science, 2(3), 66-77.

Asuquo, A. I., Akpan, A. U., \& Tapang, A. T. (2012). Nigerian pension reforms and management: New strategies for rewarding past intellectuals towards sustainable development in the third world. USA, Global Journal of Management and Business, 12(13), 11-18.

Asuquo, A. I., Fadenipo, A. A., Ogbeche, L. O., \& Ahonkhai, O. E. (2017). Effect of inflation accounting on business income measurement of quoted manufacturing companies in Nigeria. Imperial Journal of Interdisciplinary Research, 3(1), 1886-1894.

Axel, L. (1968). Keynesian economies and the economics of Keynes. New York: Oxford University Press.

Baumol, W. J., \& Blinder, A. S. (1988). Economics principle and policy (4th ed.). New York: Harcourt Brace Jovanovich, lnc.

Bradley, R. S. (1989). The economy today (4th ed.). New York: Random House.

Budget of Realism [BoR]. (1999, January). Saturday Champion (p. 34).

Chambers Dictionary [CD]. (1982). Ibadan: Spectrum Book.

Effiong, S. A., Udoayang, J. O., \& Asuquo, A. I. (2011). Correlational and Differential influence of historical cost and current cost profits on the operating capabilities of the firm. International Journal of Financial Research, 2(1), 64-70. https://doi.org/10.5430/ijfr.v2n1p64

Federal Office of Statistics [FOS]. (2019). Review of the Nigerian Economy: Lagos.

Friedman, M. (1953). The methodology of positive economics: Essays in positive economics. Chicago: University of Chicago Press.

Glautier, M. W. E., \& Underdown, B. (1990). Accounting theory and practice. London: ELBS.

James, A. K., \& Richard, S. T. (1982). Economics, private and public choice (4th ed.). USA: Harcourt Bruce, Javanovich.

Lawal, O. A. (1985). 'A'Level Economics of West Africa. Lbadan: Heinemann Educational Books (Nig.) Limited.

Lipsey, R. O. (1982). An introduction to positive economic (5th ed.). London: ELBS, Weildenfold \& Nelson.

Longe, G. A. E. (2007). Managing the Civil Service in a Presidential System of Government: Issues, Problems and Prospects. ASCON Journal of Management, 1(2), 20-36.

Ndebbio, J. U. E. (1997). Strategies for better socio-economic management in Nigeria's ultimate goals: The Journey so far. In E. K. M. Ogon (Ed.), Calabar: University of Calabar Press (pp. 50-61).

Nwana, O. L. (1981). An introduction to educational research. Ibadan: Heinemann educational Books Limited.

Osuala, E. L. (1982). Introduction to research methodology. Onitsha: Africana FEP Publishers Limited.

Parkin, M. (1989). Economics for professional and business studies (4th ed.). Onitsha: Random House.

Public Service Handbook [PSH]. (1972). Federal Ministry of Establishment and Service Matters. Component of Tenth National Plan [CONP]. Calabar Municipal Government, Cross River State.

Salif, A. (1999, November). Tarring the shrew: News watch magazine (p. 3).

Stephen, M. A. (2019). Correlation between earnings and consumption of public servants. Unpublished MBA Project, University of Calabar, Calabar.

Timothy, A. S. (2018). Consequences of price Changes: Macro approach. Nigeria: Digital \& Advanced Publishers.

Ubeku, A. K. (1975). Personnel management in Nigeria. Benin City: Ethiope Publishing Corporation.

Udeme, A. S., \& Akpan, A. S. (2016). Effect of inflation on prices of consumable merchandise. International Journal of Accounting and Financial Research, 2(3), 20-29. 
Udoayang, J. O., \& Asuquo, A. I. (2009). Accounting form minimum wage and its implication on the living standard of civil servants in Cross State - Nigeria. Journal of Business Administration and Management, 4(3), 87-98.

Uwah, U. E., \& Asuquo, A. I. (2016). Capital budgeting processes and wealth maximization objectives: Implications for firms in Nigeria. Research Journal of Finance and Accounting, 7(10), 73-85.

William, B., \& Holen, A. (2003). Civil Service: The New Encyclopedia Britannica (15th ed.).

Wusen, T. M. (2016). Simplified approaches to understanding macro-economic. Calabar: Index Educational Publishers.

\section{Copyrights}

Copyright for this article is retained by the author(s), with first publication rights granted to the journal.

This is an open-access article distributed under the terms and conditions of the Creative Commons Attribution license (http://creativecommons.org/licenses/by/4.0/). 